\title{
The Rural Councillor as Development Agent : An Uneasy Connection? A Report from Senegal
}

\section{Bernhard Venema}

\section{OpenEdition}

\section{Journals}

Édition électronique

URL : http://journals.openedition.org/apad/605

DOI : $10.4000 /$ apad. 605

ISSN : 1950-6929

Éditeur

LIT Verlag

Édition imprimée

Date de publication : 1 décembre 1996

Référence électronique

Bernhard Venema, «The Rural Councillor as Development Agent : An Uneasy Connection? A Report from Senegal », Bulletin de l'APAD [En ligne], 12 | 1996, mis en ligne le 25 avril 2007, consulté le 07 septembre 2020. URL : http://journals.openedition.org/apad/605 ; DOI : https://doi.org/10.4000/apad. 605

Ce document a été généré automatiquement le 7 septembre 2020.

Bulletin de l'APAD 


\title{
The Rural Councillor as Development Agent : An Uneasy Connection? A Report from Senegal
}

\author{
Bernhard Venema
}

1 The rural council in Senegal is commissioned to play an important role in development. The council is the formal authority to decide on land distribution and land disputes. In addition, it is authorized to collect the yearly head tax and market fees and to decide which collective utilities or projects will be financed. In every arrondissement there is a technical team, the staff of the 'Centre d'Expansion Rural' (CER), which has been created to assist the council in planning and implementation. In the case of development interventions by outsiders in the jurisdiction of the council, it has at least the right to be informed and to propose suggestions. One can say that in the arrondissement the field of development agencies is composed of non-governmental organizations and semi-government agencies as the external actors, the rural council as actor at the level of the rural community, local groups and associations at the village level and the CER as supporting actor at the level of the arrondissement. The council, thus, seems to have a crucial linkage position between the village and higher level.

2 In development theory it is argued that decentralization of government administration and participation of the local population in development will result in higher performance than top down planning and implementation. Therefore, in most African states the government's role in economic development has been curtailed. At the same time government organization has become more decentralized while there is more room for manoeuvre for rural councils and NGOs. Thus, in practice councils should indeed be able to act as a development agency. Many councillors maintain that they are able to work properly. According to one author, many Senegalese councils are democratically organized and the councillors are able to work independently and to remain in touch with their constituency. The real problems are financial ones (Sy 1996).

Looking at local elected bodies from a scientific point of view, the prospects are more gloomy. In Africa most central governments are not so much interested in the 
well-being of their citizens as in maintaining privileged positions for themselves and their clients. In order to keep the system running, favours are exchanged for political support. Such neopatrimonial political systems are characterized by clientalism which pervades ail political life ; as a consequence, a great part of government resources are withdrawn from public services.

4 Social scientists argue that Senegal's political system must be analysed in this way. Although Senegal may have a long tradition of multiparty democracy, this is not relevant for this discussion. Such formal issues may be stressed in political propaganda, essential however is the fact that the political system has not been changed. In their overview of the political systems in Africa, Buijtenhuijs and Thiriot (1995:13) conclude that in the absence of a political culture of participation and accountability, multiparty democracy is likely to remain confined to competition among the political elite. As regards Senegal, they argue that the democratic structures simply have been grafted onto the neo-patrimonial structures (see also Kante 1994, Diop 1993, Coulon and Cruise O'Brien 1989).

5 So the devolution of authority to democratic elected councils seems to be no more than a superficial issue which maintains the political relations. Borhaug (1994) argues in an interesting annotated bibliography that decentralization and democracy effect the local balance of power. This means that government staff and politicians will do everything to maintain their position, which may even result in clientalism increasing in importance.

6 The scientific perspective is common among those who have critically examined the role of the Senegalese rural councils. Thus Blundo argues, that the government officials and party politicians are able to manipulate the council, which results into a clientalistic use of the resources of the council. As a consequence farmers have a negative opinion of the council and they try to keep it at bay $(1991: 124,1995: 77)$. Due to factionalism and rivalry councillors may even block peasant leaders who wish to start a development project in the community. He concludes that farmers associations and local councils do not contribute to the resurgence of civil society, as is often argued. This he considers to be ill-founded optimism as these institutions function according to a clientalistic logic (1995: 96). In the same way Gellar views the rural council. According to him, the villagers regard the councils as highly politicized institutions which use their power and resources to reward those co-operating with the state and the ruling party (1996:19, see also Lachenmann, 1990). These scholars have in common the idea that local political institutions are the domain of political entrepreneurs who act in a self-interested manner and are able to achieve their aims.

7 The analysis of these scholars is based on anthropological theories called transactionalism, exchange theory, network analysis, and actor theory. The guiding analytical concepts are actor, networks, transactions, brokers, the notion of multiple realities, and arenas of struggle. This theoretical approach denounces the 'populistic' approach which sees the 'community' as homogeneous: the various interests and opportunities within local society must have ample attention. Local brokers are the social actors who operate as intermediaries in the local arena trying to bring different parties together and by doing so, trying to improve their position (Bierschenk and Olivier de Sardan 1993).

8 However, in this type of analysis actors are sometimes viewed as political entrepreneurs, whose decisions are shaped by self-interest and careerism only. What is 
disregarded is the fact that actors also have to act according to local considerations of what is appropriate in the particular context. In villages where people have lived together for decades, local control mechanisms and old patterns of prestige and co-operation are most likely still operative. The authors who define the Senegalese state as clientalistic, admit at the same time that there are many local mutual aid mechanisms based on kin, neighbourhood, caste, and marabout-taalibe relationship (Gellar 1996, Coulon and Cruise O'Brien 1989). These authors admit that traditional control mechanisms continue to function too and that these influence political behaviour of the councillors. For example, they state that councillors deliberate with the village head and eider before a decision on land distribution is taken. Thus, implicitly they admit that the rural councillor is not only related upwards in a clientalistic fashion to government officials but that he has to take local authority patterns into account as well.

Long (1992), one of the founders of the social actor and agency theory in development sociology, argues that ail societies contain a repertoire of different life styles and rationalities which they utilize in their search for order and meaning. In this context, Olivier de Sardan speaks about different stocks de représentations; generalizing from one stock only resulting in unacceptable stereotypes (1995: 70). It is therefore useful to distinguish between views and expectations villagers have of political life at national and regional level and views as regards local politicians. Politicians at the wider lever are believed to act as entrepreneurs who manipulate kinship and neighbourhood in a clientalistic fashion, which eventually results in disappointment and frustration on the side of the clients. Politicians at the village level are believed to act according to local criteria of prestige and legitimacy too. So the village consensuelle, in the words of Olivier de Sardan, may not be a stereotype but is often a realistic description of what is observed. According to Blundo, peasant leaders must be cultural insiders to attract a following, and we would apply this to councillors too.

In the context of this discussion I want to examine the role of the council of Kaymor as a development agency. I will also analyse if individual councillors operate as development brokers.

The rural community of Kaymor, arrondissement Medina Sabakh

11 The arrondissement Medina Sabakh is situated in the southern part of the Kaolack region. The total area of the arrondissement is $601 \mathrm{~km} 2$ and it has 32.892 inhabitants ${ }^{1}$. The majority of the population belongs to the Wolof ethnie group ( $86 \%$ ), the others are Toucouleur, Peulh or otherwise (Seck 1995).

12 The arrondissement is composed of three rural communities (communauté rurale), Kaymor, N'Gayene en Medina Sabakh. Each community counts several tens of villages : 23,23 and 58 respectively. The villages are relatively small, the average number of inhabitants is merely 316 . Every rural community has a council, with an office in the central village. The villages are not far away from the central village, the maximum distance is no more than $10 \mathrm{~km}$. The council of Kaymor officially has 24 members, but since the election of 1990 two members have died. In principle, a third of the councillors are designated by the members of the local sections of the co-operative of Kaymor. In the community of Kaymor there are nine sections, six have a representative (désigné) in the council ${ }^{2}$.

13 The yearly rainfall in the arrondissement varies between 500 and $900 \mathrm{~mm}$. Through the area runs a secondary branch of the Gambia river, the Bao-Bolong, which itself has 
tertiary affluents. When the rainfall is high, the shallow parts of the land (bas-fonds) may become pools with water after the rainy season. Agriculture and cattle husbandry are the main sources of livelihood. The clearance of land and the need for firewood finished the forest off : there only remains astate forest (forêt classée) of 1900 ha..

The first settlers in the area were probably Toucouleur. To this day the community counts old Toucouleur centres as Diama Thiewie, but there are also Toucouleur villages recently created. The first Wolof settled in the area probably in the 17th century. They were from Manding origin, but became wolofised during the course of time. The Cisse and Toure families are among those who settled long ago and who were hot gospellers of the Islam. They founded the villages Kaymor, Thysse-Kaymor, Pacala, N'Dau and others. These families were and still are quite influential in the area.

The Cisse and Toure families were from the class of the freebom (diambour). They were engaged in agriculture and cattle husbandry. Their clients were families from the class of artisans (nieenio) who made the necessary farm implements and leatherwork. These were sidelines, as agriculture was their main occupation. In addition, these families had slave families (diam) who did most of the agricultural labour. They worked for their master five mornings a week, the remaining time tilling their own fields and herding their own cattle. No social class was excluded from entitlement to land.

After the pacification of Saloum in 1887, the French colonial government left the social hierarchy untouched. Only after internal warfare was ended and the cultivation of groundnut had become common, the government propagated that domestic slaves should no longer work for their master and start completely for themselves. In Saloum slaves from elsewhere established themselves as farmer or labourer at the railways from the 1920's onwards.

17 Many Mouride marabouts have profited from the situation to found a religious community (dara) in Saloum, which attracted many followers from slave origin (Klein $1993: 185$ ). They were accorded their own plots after having worked for the marabout a number of years. Especially the marabout family Serign Aliou Seck founded many dara in the arrondissement which now have developed into actual villages as Padaf and Darou Khoudos. At this moment dara are no longer founded. Instead of working several years for their marabout, his followers help to cultivate his farm a number of days each year.

18 In Medina Sabakh, the slaves left their master only in the thirties in order to become independent farmers. Most ex-slaves preferred to live in their original village or in a hamlet nearby. People still know the master-slave relations, which are reconfirmed in the exchange of presents at ceremonies, where the person higher in rank are obliged to give more generously.

So the economic emancipation of the slaves seems not to have changed the social ranking. Each class has its own residential quarter and marries endogamously. The diambour are those of highest status. They occupy the local political and religious positions because they are the founders of the villages and the descendants of families of marabout origin. Until today, ail village heads, Imams and teachers in the local Koranic schools are freebom; however, this is not the case in villages without diambour.

20 Next in rank are the diam. They marry endogamously, but freebom sometimes marry a diam woman. Diambour men sometimes marry a slave-bom woman as their fifth wife ; in that case the children inherit their status from their mother. It happens occasionally 
that a freebom redeems a slave woman before marrying her ; in that case the children inherit the class of their father.

21 Lowest in rank are the craftsmen (nieenio): the leatherworkers, the blacksmiths and minstrels. Their main activity is agriculture, however. The nieenio only marry within their group, a marriage with a person from a different class is taboo. Of the total population in the community of Kaymor, as in the arrondissement, about half is freebom, about half is slave-bom and about ten percent is artisan.

In daily life social ranking is not evident. Taboos to communicate across one's class are therefore absent and people of different class are friends who can co-operate. Compared to a generation ago it is now not appropriate to refer to class. We will take a closer look at this in order to see if social class affects membership of the rural council.

Decentralization in Medina Sabakh

Till 1983 government policy in this area was mainly directed to production increase by agricultural extension and the supply of production credit. The government departments at the countryside co-operated in rural extension centres, the Centres d'Expansion Rurale (CER), a sort of multidisciplinary team for rural development. This team was located in the headquarters of each arrondissement, mostly composed of an agricultural extension worker, a veterinary assistant, a forestry agent, a home economist agent, and a co-operative assistant. In the headquarters of the district (département) there was also some government staff to help the field agents in their work.

24 It is a common view that CER hardly contributed to agricultural development (Vengroff and Johnston 1985, Ba 1985, Kante 1993). In the first place this was due to the very limited size of the field staff. A calculation of the number of field staff in 1964 resulted in a density of only one fieldworker for every 15.500 inhabitants. Secondly, there was the chronic lack of transport facilities to visit the villages. In addition, part of the work of CER was administrative, such as the registration of credit supply or the checking of illegal woodcutting in the state forests. For these and other reasons the CER staff lacked the motivation to work properly.

25 For agricultural development the regional development organizations were more important ; in Saloum this was the Société de Développement et de Vulgarisation Agricole (SODEVA). SODEVA was a donor-financed agency focusing on groundnut production. It aimed to increase production by means of an intensive extension program. The village co-operative which handled the groundnuts granted the credit to buy seed, fertilizer and farm implements. Next to SODEVA there was also an agency (SODECOTON) that promoted the cultivation of cotton using the same approach.

This 'interventionist approach' did increase agricultural production. However, the farmers became indebted by the volume of production credit in combination with crop failures due to low rainfall (Venema 1978: 68-71). The farmers could not pay their instalments and the co-operatives went bankrupt. In 1984, as part of the Structural Adjustment Policy, the co-operatives lost their buying monopoly and the umbrella organization, the Office National de Coopération et d'Assistance du Developpement (ONCAD), was dissolved. From now on the co-operative only delivered seed and fertilizer on credit and only after a large down payment. Another policy was the discontinuation of SODEVA and other regional intervention agencies. Henceforth the idea was that the 
population itself had to initiate activities in order to obtain certain goals. The CER no longer contacted the population, but now the reverse was required.

The government stimulated the population to form other associations in addition to the sections villageoises. The CER and the rural councils summoned to set up groups (groupements). This would facilitate their own work and increase the likelihood to be approached by NGOs. The groupements were rather loose associations lacking any juridical status. Some had a saving deposit on a bank, which they could use to buy seed or farm implements, but they had no other official status. However, the CER and councils also propagated the founding of more formal organizations; since the law of 11 May 1984 Groupements d'Interêt Economique (GIE) could be created. Several people could unite for a common economic goal on a voluntary basis. After having been registered at court and after a large down payment, the GIE was allowed to borrow money at the bank.

As part of the decentralization policy, a council was elected in each rural community in the region in 1974. These councils had three important tasks. In the first place they became responsible for the allocation of land. Formerly this had been the responsibility of the village head and the founding families. The council even has the right to expropriate land. According to a government decree, land that has been left unused for three years could be taken over by the council. Apart from land used for agriculture, the council also supervises the common pastures. Since the code of 4 February 1993 it may even make proposals to the subdistrict officer (sous-préfect) to exploit state forests.

The second task of the council is to collect the head tax and decide how to use it for development purposes. Every person between 14 and 60 years old is required to pay tax, 1000 fCFA per person. With this money the council finances the reparation of wells, the building of classrooms and so on. Until 1990 the state had retained tutelary powers over the council, but after the Administrative Reform of 1990 this has been abolished. The budget is now administrated by the council itself. Lastly, the council has to make village residential plans and decide on cattle tracks.

While the role of government in development decreased, the number of NGOs in the area increased. One of the first NGOs in the area was Caritas, with its headquarters in Kaolack. Since the sixties the American Peace Corps started to work in the district. The past ten years several NGOs and semi-government agencies (QUANGOs) have however started to work in the arrondissement: Africare, POGV, PNVA, SODEVA, ISRA and the Mission Norvegienne ${ }^{3}$. The NGOs are located in the headquarters of the arrondissement, Medina Sabakh. We estimate that about 35 of the 104 villages have links with these NGOs and QUANGOs ${ }^{4}$. In the community Kaymor only Kaymor, Passy Kaymor, ThysseKaymor, keur Dianko, keur Bacary, keur Samba Die, and Sonkorong are involved. Most NGO activities take place in the community Medina Sabakh where they have their office.

31 As argued in the introduction, the council has a crucial linkage position between the village level where groups and GIEs are active and the higher level where the CER, QUANGOs and NGOs are operating. However, it remains to be seen whether it makes this linkage effective.

The composition of the council 
The size of the council depends on the number of inhabitants in the rural community, ranging from 16 up to 28 members. The rural council of Medina Sabakh is, however, larger than officially allowed (29 instead of 28).

The local party branches propose candidates for the election list, but the final decision is taken by the party leaders of the département. Two criteria were mentioned as being the most important to become elected: political activity in the party and a good reputation of the candidate in the community.

The actual members of the council of Kaymor are all members of the government party, the Parti Socialist (PS). This has been the case since the election of the first council in 1974. The PS has always had most of the votes in the countryside and the 'winner takes ail system' entails that it could occupy ail seats ${ }^{5}$. At the end of the eighties other parties became more important. However, in 1990 the opposition parties boycotted the election and again the PS could monopolize the council. In theory it is still possible that members of other parties can be elected as a councillor, in fact as a désigné, but in Kaymor this was not the case.

35 The council reflects the composition of the local population. The rule is that government staff cannot figure as a candidate. Neither the local extension workers nor the teachers were a councillor. The advantage of this practice is that the council reflects the interest of the autochtonous population, the disadvantage is that those with a broader vision, as for example the teachers, cannot be active as councillor ${ }^{6}$.

The local autochtonous population also adheres to this practice because they themselves deny the Peulh from Guinea access to the council. These Peulh started as navetane in the area, but some have now settled themselves as shopkeepers. Although they are among the most wealthy, for the moment being they are still considered strangers. Even if they are party-members, they are not elected in the council.

Youngsters and women are clearly underrepresented. Since the election of 1990, the party has for the first time accepted the principle that women and young men can be on the list. In Kaymor the council members included one woman and one young man. is in his mid-30s, between men over 60 years old and one man in his forties ${ }^{7}$. Once again, local criteria of ranking determine access to the council. heads have been elected as councillor. The council of Kaymor counts four village heads among its members.

40 As has been stated, the party ultimately decides who can run as councillor. To have local support, the party has made sure that the candidates are from different villages of the community. The councillors of Kaymor have been selected from the following villages: Kaymor: 4, Sonkorong: 3, Ndimbe Birane : 2, Samba Die : 2, twelve villages : each 1 . From this it follows that 15 from the 23 villages have a representative in the council. The larger villages have one representative in the council (Couloumbodou, Thysse-Kaymor and keur Bacary), or more than one (Kaymor, Sonkorong) ${ }^{8}$.

The composition of the council of Kaymor reflects the class division in the community. The council counts 9 diambour, 11 diam, and two members without specific class distinction. Five slave-bom members are designés who have less prestige than the elected councillors. In other councils the diambour are quite often over represented 9 
Apparently exceptions as in Kaymor do occur which means that party politicians attach less importance to these traditional criteria of ranking.

In addition, people who are not Wolof have access to the council. Thus, the council of Kaymor has 4 Peulh and 1 Serer as a member. However, the Toucouleur are not represented in the council. As was the case for social class, ethnic origin is less well represented in Medina Sabakh ${ }^{10}$.

43 I can conclude that the council does not necessarily reflect the official directives as regards repartition between numbers of élus and designés. In addition, local criteria of ranking are taken into account. Village heads and eider of the autochtonous families are the backbone of the council. In the words of Blundo (1991: 131), the council is essentially composed of ainés sociaux. What is clearly particular, is that also the lower classes and ethnic minorities are represented in the council. These criteria of stratification seem to lose some of their importance, but how developments will be in the future is not clear.

The tendances in the council : factionalism or personal preferences?

Knowing what criteria are taken into account to become elected as a councillor, I will now look into the operation of the council. It appears that the functioning of the council is hampered by factionalism and the misuse of funds. This has also been established by other authors (Blundo 1991, Savané 1983).

After the PS took ail seats in the last local elections in 1990, most rural councils were split up into two or more tendances. This means that some councillors have ties with party leader A and others with party leader B. Both party leaders have relations with politicians at a higher level. The tendances have nothing to do with political arguments. What seems important is to have good connections.

The council of Kaymor is divided into tendance A (15 members) and tendance B (7 members). The leader of tendance $\mathrm{A}$ at the level of the département is Samou Toure, a government official who has connections with Moustapha Niasse, minister of Foreign Affairs. The leader of tendance Bis Modou A'Bass Ba, a member of parliament and ex-minister. The phenomenon of tendances results into rivalries and situations of stalemate. No wonder several people do not in any way wish to be involved with the council.

A. Casus : the opinion of the secretary of a daira

47 The secretary of a religious organization (daira) asked one of the authors to help the daira so that it could undertake income-generating activities. He did not want to have any relationship with the council: "The council is only interested in politics. Sound criteria are not important at all. What is the case is that those of the same tendance collaborate in order to cash in advantages. That is the reason I don't want to have anything to do with the council". However, this did not prevent him being a member of the PS. He told us that he was party-member because he did not want to become isolated.

48 NGO representatives may decide not to work in a village because of the conflicts between tendances. The councillors of the village Medina Sabakh opposed each other in such a way that an NGO agent decided in 1995 to work in this village no longer but rather in smaller villages (Bierman 1995 : 51). However, she also mentioned that the man preferred to work in small surveyable villages. In 1995, USAID started with the preparations for a large project on natural resource management in the area in which 
it would involve the population, other NGOs and the council. USAID has, however, avoided close collaboration with the council. Although USAID's policy is officially to link up with government institutions, in practice they decided to work together with a management committee with a weak link to the council. In this committee three councillors are active ${ }^{11}$. In Medina Sabakb, however, two NGOs co-operate with the council, for example in selecting the villages (Bierman $1995: 51,55$ ).

Factionalism does not only occur in the council but also in the organizations that have political ties, such as the co-operative.

B. Casus : the co-operative of Kaymor by the council (see section 7). He made it clear on several occasions that he personally had a bad experience with the council. However, if other people wanted to join in, he would correct them because, according to hi $\mathrm{m}$, they had nothing to complain of. puzzled, We asked him why he held a brief for the council. He explained that some people liked to complain about the council in front of foreigners, but that they had nothing to complain about. Apparently, critisizing the council is part of personal strategies.

D. Casus : a personal strategy of the councillor of N'Dakhar

55 As most councillors, the vice-chairman belonged to tendance A. However, he suddenly switched over to tendance B. He explained that his son had caused an accident with his taxi de brousse and had lost his driving license. He had therefore visited the party leader of tendance A to discuss the return of the driving license. The party leader did not want to receive him in his office. He then decided to become a member of tendance $B$.

56 Apparently the division into factions inhibits the activities of the council. However, factionalism is not based on structural divisions within the rural community. Shift are 
easily made and people could cite several examples. Therefore, the presence of tendances does not prevent the population to co-operate in many ways, as for example in building new mosques. Notwithstanding the existence of tendances, other social control mechanisms do continue to operate as well.

The council as development promoter

Decentralization may imply that development activities are now promoted by individuals who lack the capacity to do this properly. For Senegal the government takes the view that the council can act as a promoter because it is assisted by the CER. However, as already argued, the CER is not capable of assisting sufficiently. Nowadays most CERs have a car at their disposition, but a CER has a budget which allows him to buy only 600 litre of diesel a year. It is clear that the CER can hardly reach the villages in the arrondissement at all. Therefore the CER turns to the council for a contribution to the travelling expenses. However, this can hardly be considered to solve the problem.

The council indeed has a budget of its own in order to finance activities approved by the council. The budget is relatively small and part of it disappears as fixed costs ${ }^{12}$. The councils are therefore not in a position to spend large amounts on travelling expenses. That is why most councils have appointed their own committees to do the real work, such as managing a millet mill or supporting the anti-bushfire campaign. Quite often a councillor is designated to act as a technical advisor in his village.

The committees, started by the CER and councils, appeared to function only superficially. According to the CER the arrondissement has 64 committees for reforestation and fighting bushfires. However, the informants stated that a large majority of these committees only existed on paper. In fact there were only eight small tree nurseries in the whole arrondissement.

60 The reason for this is quite clear. In view of other priorities, investment in reforestation and for fighting bushfires had to remain small. In Kaymor the council only devoted fCFA $150-250.000$ a year to reforestation. In addition, the money was given directly to the CER as a compensation for its extension work. Left without any financial support, the committees were not enterprising at all ${ }^{13}$. In Senegal collective action to control forest degradation is therefore rare.

61 As mentioned in section 5, the council and the CER also assist groups, most of which are women's groups. They initiated many such groups. According to the CER and my own information there are at least 100 groupements in the arrondissement, 50 of which are women's groups. In the community of Kaymor there were already 26 groupements jeminin.

62 Most of these groups have obtained a plot of land and materials like seed, rakes and so on to grow vegetables, others exploit a millet mill. In theory these groups should receive assistance from a councillor in order to work properly. However, most councillors are uneducated and are not able to support the group in bookkeeping and often lack the technical expertise as far as new innovations are concerned.

63 So the councillors failed to manage the grain mills properly. Since 1976 the council elected one village each year which received a millet mill. From the revenues a quarter should be reserved for a replacement fund and a quarter used for an activity benefiting the whole village. The mills were assigned to a miller and the councillor of the village would supervise him. Between 1976 and 1987 fifteen mills, with a total value of 16.5 million fCFA, have been attributed to villages in the community of Kaymor. In 1987 only 
in one village a mill was still running. All other mills had run into technical problems, which had quite soon resulted in their collapse. Because the revenues from milling were used for other goals than replacement, the women had to return to manual pounding. Nowadays, mills are only given to a women's group which is required to select a management committee composed of three women and assisted by the local councillor.

The involvement of the councillors in the groups may have the effect that some groups are rather superficial. Some have been founded without much deliberation (see section 5). Because of this, some board members are only slightly involved in the proper management of their group. An often heard complaint is that board members borrow from the group's funds. This happens in women's groups, but also in other groups ${ }^{14}$.

Independently, the chairman and the vice-chairman of the council of Kaymor acknowledged this fact and stated that since a decade they preferred investment in infrastructure to financing groups or economic projects. Investment in wells or community buildings can be made more easily without the need for intensive management. The table below shows the preference for investment in infrastructure.

Expenditure in 1994 by the councils in the arrondissement :

- infrastructure : $45 \%$

- education/youth : $19.96 \%$

- hydr./electricity : $15.9 \%$

- animal vaccination pro gram : $9.9 \%$

- health : $8.3 \%$

Although many investments have been ill-conceived and ill-performed, many people believe that the council tries to learn from past mistakes and the case of the millet mill was cited. The population continues to pay its tax to the council. Every year the village head establishes the tax list which is then checked by the council and the sous-prefect. However, most often the village head keeps those who are without resources from the list. Because the councillors co-operate and the sous-prefect is not informed, this list becomes definitive. According to our informants, about a quarter is exempted from paying tax, which explains why the official number of inhabitants is below the real number (section 2). Apart from those not mentioned on the list, all others pay their tax. Thus, government officials have no argument that tax has not been paid by everyone. Because the community of Kaymor has a payment rate of $100 \%$, it receives the additional premium of 3 million fCFA (the so-called Fonds de Concours). Kaymor has paid its tax for $100 \%$ since 1981 ; in the community Medina Sabakh this is the case since 1991. The councillors are very proud of this because, according to them, people have confidence in their performance.

The conclusion is therefore that the council is the commissioned organ to act as a development organ, but is hardly able to do it properly. However, the council seems ready to learn from past experiences and the councillors have not lost confidence. Complaining about the council is probably is not motivated by deep distrust, but is part of personal strategies.

The rural council as guardian of land

69 Traditionally, the village chief and the autochtonous families were responsible for land allocation. However, by the Law on the National Domain of 1964 it was stipulated that the council is responsible for the allocation of land ${ }^{15}$. Below several occasions dealing 
with land allocation are described. From the cases it follows that the council has become an important instrument in land allocation, and that it in this is assisted by the village head.

When strangers ask for land, both the council and the village head are involved. Sometimes both functions are performed by the same person. In most cases the request for land is posed to the village head who then contacts the council. After the council has decided favourably on the request, the concerned party, the village head and a councillor go to the collective land in order to mark a parcel of land to be allocated. Most often the eider of the neighbourhood are asked for their opinion too in order to check if there is no claim by other families on the land (see also Bierman $1995: 73)^{16}$.

However, when local associations need land they turn directly to the council and not to the village head, because the CER and councillors themselves have summoned them to create a group. Because there has been some pressure to form groups and to undertake activities, the council cannot refuse groups' requests for land. When the allocation concerns a plot within the village residential area or close to collectively owned village land, a problem might arise because traditionally the village head and eider decide in such matters.

A. Case : the allocation of public village land in Sonkorong

72 In 1991 the two councillors of Sonkorong each created a women's group. Because these groups wanted to start to grow vegetables, they turned to the council requesting a plot. One councillor proposed to give a parcel of his own land, near by the village and suitable for horticulture. The council agreed. The search for a plot for the other women's group posed more problems. The second councillor decided that part of the public land of the village should be given to this group. However, the village head became angry and confiscated the area and prohibited any activity. He told the councillor that allocation of public land was his affair. Since then the plot has not been cultivated. Il is not excluded that the slave origin of the councillor may have played a role in this conflict.

In the following the case is described of a farmer whose land was to a large extent not tilled. Part oof it was claimed by another farmer who did not have enough land. Traditionally such land could never be claimed. However, the claimant referred to the new law and asked the council for help. However, he avoided taking his request to the village head.

B. Casus : former extension agent who settled in the community of Kaymor

In the early eighties an extension worker married a village girl. He did not do this without some calculation. Due to cuts in expenditure he had to quit his job and had to look for other revenues. He therefore married the girl who had inherited 20 hectare of land from her father, who had no sons and whose daughters lived elsewhere with their husbands. Now the former extension worker was a large landowner. Some years later an autochtonous family in Sonkorong asked the village head for part of the land because they did not have enough to earn a living. However, the village head did not intervene himself but suggested to contact the council. Because the extension worker had not been able to till all the land, the council decided to give half of it to the claimant. The extension worker was very angry and contacted the village head again. However, the village head was afraid to intervene and so he lost the land. because some councillors act as village heads as well. But we also have to take into 
account another process. As regards the clearing of distant collective land, mostly used as pasture land, neither the council nor the village head play a role. Only a generation ago, it was the village head and the founders who decided who could clear the land (Venema 1978: 104). Now villagers clear distant land secretly. Although the village head or the council know what is happening, they do not intervene. This practice has become current and even councillors themselves join in this activity. Most often the clearing of land is in the hands of the most wealthy and influential in the village because they have enough labourers for clearing land. Thus the council and village head have lost control over the remaining pasture land.

C. Casus : land clearance in Kaymor

Since 1977 land in the depressions near Kaymor are cleared for vegetable gardens and orchards. Not only influential people, like the village head and the Imam, have cleared gardens here, but recently, the women too. Although the area was used as pasture land, farmers with cattle did not intervene because they were landowners too. The fact that notables themselves had cleared land, became for others the example to do likewise. The Imam and village head have already officially registered their land, the others not yet.

77 Leasing and selling of land occurs frequently in Senegal (Kante 1993). In the arrondissement land is now leased too and even pawned. Land is increasingly seen as privately owned property, although legally it is owned by the state. In 1995 land was leased for about fCFA 5000- 15000 per ha. Even councillors have a stake in land lease. Land can even be sold. Although land lease is discussed in public, the selling of land occurs secretly. However, there is one case known to everybody. The council of Medina Sabakh itself has bought land from a farmer for fCFA $11 / 2$ million in order to extend the market square (Bierman 1995 : 53).

So we see that the introduction of the Law on the National Domain led to a rather ambiguous situation. The elected representatives try to increase their say and they seem to succeed. But there also seems to be a power gap. Land clearers and land buyers profit from this situation. Now even women become landowner since both the traditional elite and the council are not strong enough to prevent these developments. This process limits the role of the council as guardian of land.

The individual councillor as development broker

79 So far I have made general observations concerning the council as a whole as a development agent. Now the individual councillors are examined. It is argued that some councillors are more active as a development agent than others. Below the most dynamic councillors are mentioned ${ }^{17}$.

A. Councillor A

80 Councillor A is the son of the Imam of Kaymor, about 45 years old and with several years of secondary education. He is a councillor and representative of the council in the development committee of the arrondissement and the département. The party gave him a motorbike because of his many political activities. People whisper that in fact he rules the council because of his intensive contacts with the chairman. Although he has a fraudulent past, known to everybody, he succeeded to obtain a key position in the new USAID project. As chairman of the management committee and as chairman of the executive committee he will administrate billions of francs CFA. He is not married and has no interest in farming. His one and only business is politics. As secretary of the council he receives an income for keeping the civil registration. 


\section{B. Councillor B}

81 Councillor B is the son of the village chief of Kaymor and is the representative of the youth in the council. He is in his mid-30s. He has several years of secondary education and expresses himself well in French and even speaks some English. He has worked for some years in the catering sector in Gambia, but his father has asked him to come back to assist him in his work. He was always on the hands of the Peace Corps volunteers who have been in Kaymor for ten years now. Now he is an expert in agroforestry and resource conservation. He is president of the committee of reforestation of Kaymor and owns a tree nursery. Furthermore, he is the technical advisor of one of the women's groups of Kaymor and of a group of Toucouleur youngsters in the neighbourhood who have a collective garden.

C. Councillor $\mathrm{C}$

Councillor $C$ is the village head of Thysse-Kaymor and member of the council. He is the president of the daira of Thysse-Kaymor counting about 100 members. He only has a Koranic education, but he understands some French. He is in his mid-40s. His main occupation is farming and livestock holding, but he is also greatly involved in politics as he is a party official at the arrondissement level. He succeeded in becoming a member of the USAID management committee too. His wife is the treasurer of the women's group of Thysse-Kaymor. He is fairly open-minded and told the authors how the $100 \%$ tax rate was achieved in the rural community.

83 However, not only councillors are dynamic development agents. Others too try to play a role in development ${ }^{18}$.

D. Former extension agent

84 He is a former extension worker who had to resign because staff was cut down. He settled in the area and has been a large farmer for the past ten years. He has several years of secondary education and speaks fluent French. He is about forty years old. He is a member of the USAID management committee and also of the Executive Committee. He is the secretary of the women's group of Sonkorong and of the daira of Sonkorong which is involved in several economic activities like trade in second-hand farm equipment, fattening of oxen and so on. Furthermore, he is, in name, the treasurer of the youth association of Sonkorong, but actually he is the leader. When USAID appeared on the scene, he quickly created a GIE. As already mentioned, he operates outside the official political channels because he looks down upon party politics.

E. Local carpenter in Kaymor

He grew up in the regional centre of Kaffrine where he followed secondary school education which he did not complete. Eight years ago he returned to Kaymor where he started his job as a carpenter. He belongs to the class of minstrels and is middle-aged. He has become chairman of the Chamber of Crafts of the rural community of Kaymor. He tries to persuade people to become a member of the Chamber too. In the beginning this was not easy because nobody believed such a membership could be in their interest. Now the Chamber has 60 members. He is a member of the USAID management committee and tries to obtain support of USAID for the activities of the Chamber. For this reason he convinced the members of the Chamber to create 3 GIEs to start some common activities.

We can conclude that people who are dynamic as development agent have a number of characteristics in common. They are ail relatively young, most of them have had 
secondary education and they come from wealthy families. They have contacts outside their village because they have worked elsewhere or because they are active in political networks. For the latter the council seems to be a very good starting point. The local development agents try to manipulate USAID, but they are, however, not in a position to attract NGOs and can therefore not be considered as development brokers.

Decentralization and civil society

We have seen that several NGOs and QUANGOs are active in the arrondissement and are linked up with about a third of the villages. In addition, the villages do not profit from activities financed by 'migrant associations' (association des ressortissants). Up to now migration to towns as Dakar or Kaolack is still not common practice. One of the reasons is that formal education has been rather limited in the area and this has in some way withheld young men to look elsewhere for work. Primary schools can only be found in Kaymor, Medina Sabakh, Ndiba Layene, Sonkorong, keur Bacary and keur Ayib, and the latter three villages have schools with only two classrooms. There is no secondary education provision in the arrondissement, only in the seat of the district, Nioro du Rip. The establishment of secondary school classes has only been started in the village Medina Sabakh in 1996.

Nevertheless, decentralization entailed the creation of many committees and groups at a local level, which undertake a wide range of activities ${ }^{19}$. These groups appeared to be composed of members from different social class, even the boards have a mixed composition. The creation of groups and committees by NGOs, the CER and the council contributed to this change because their only criterion for admittance was residence.

As argued in section 2, ranking according to social class had social and symbolic implications, which effected the political structure because some occupations were reserved for the freeborn only. Now people of different castes participate in the same groupement. We have seen this to be the case in several groups and associations. When asked if co-operation between members of different class would not raise problems, it was stated that social class at this moment is no longer relevant. It was argued that education, hard work and business spirit are more important for a decent future than caste origin.

Also the role of age as a criterion of access to groups has become less important. The age of members of groups and GIEs may vary between 14 and 60 . The former age groups have disappeared and have been replaced by youth associations. But even here age may vary between 14 and 45 .

Even sex as a recruitment principle has become less important. The different groups as GIEs, daira and youth associations may have members from the other sex. However, in the boards women are in a minority. Women's groups mostly only have women as members, but there are exceptions.

The compositions of the groups ${ }^{20}$

\begin{tabular}{|l|l|l|l|l|}
\hline & Youth association & GIE & Women's groups & Daira \\
\hline \hline Class & Mixed & $\begin{array}{l}\text { Mixed } \\
\text { one exc. }\end{array}$ & Mixed & Mixed \\
\hline
\end{tabular}




\begin{tabular}{|l|l|l|l|l|}
\hline Age & Mixed & Mixed & Mixed & Mixed \\
\hline \hline Sex & Mixed & Mixed & Female only & mixed \\
\hline
\end{tabular}

The decreasing importance of class, age and sex in local groups and associations is general. This has been observed in the Sahel (Snrech 1988, Monimart 1989:54) and in Senegal for the GIEs (Callaway and Creevey 1994).

Indirectly, traditional criteria continue to play a role, however. Because of the size of a village, members of groups and GIEs are sometimes recruited from one single ward only. In that case, the members are often from the same social class. For example, the village of Medina Sabakh has a population of about 4000 inhabitants. It is composed of six wards. In total it has 3 women's groups, one is composed of diambour, the second of nieenio and the third is mixed (Bierman 1995).

Conclusion

As is argued by Borhaug (1994), decentralization in Senegal has not curtailed factionalism. Sometimes a NGO avoids villages with councillors of different tendances. Because shifts between tendances occur and due to absence of structural conflicts within the community, the tendances do not hamper the council to function as a development agency. The council has set up many grass roots organizations as GIEs, groupements and local committees. By providing land, it promotes local small-scale activities. However, the role of the council as technical advisor is performed weakly while its role as land guardian is undermined by developments in the wider society.

95 There are some indirect positive aspects too. Ascribed criteria of ranking have continued to lose importance. The lower classes have had the opportunity to emancipate for several decades now which has enfeebled the traditional hierarchy. Some slave-born, but also representatives of ethnic minorities, are therefore among the council members. Membership of grass roots organizations is no longer determined by class, age and sex. Speaking about one's social class has become inappropriate. NGOs and party politics have contributed to this social reorganization and the development of civil society. Thus, indirectly the council has also acted as a development promoter.

Some QUANQOs and NGOs link up with the council because it may act as a starting point for establishing contacts with the villages. Some councillors, especially the younger and educated ones, use their position to act as a contact person in order to have a say in these agencies. As intermediaries they are not able to attract NGOs; therefore they cannot be considered as development brokers.

In the arrondissement Medina Sabakh the composition of the council by and large reflects the local cultural values and political priorities: the members are the influential elder among which the village heads. That is why there is no opposition between the council on the one hand and the traditional elite on the other. Blundo $(1991,1995)$ also concludes that the traditional notables are in the council, but his analysis is made from a pure transactional point of view. Citing Darbon, he argues that peasant leaders are recruited among the traditional elite because they are best suited as clients of politicians (1991: 116). We argue that councillors have been elected because they represent the local community. A transactionalist approach quite often 
fails to give ample attention to the clients themselves and to the control mechanisms operating at the local level.

\section{BIBLIOGRAPHIE}

Ba T.A. 1985. "Les centres d'expansion rurale du Sénégal entre la dynamique paysanne et les structures d'Etat, Médiation ou frein pour un développement autogestionnaire ?", Mondes et Développement, 13 (52) : 621-631.

Bierman I. 1995. Plattelandsontwikkeling in Medina Sabalch, Senegal : de roi van de staat, niet-gouvernementele organisaties en boerengroepen. Scriptie CA/SNWS. Amsterdam : Vrije Universiteit.

Bierschenk T. and J-P. Olivier de Sardan 1993. "Les courtiers locaux de développement. Un programme de recherche". APAD Bulletin, 5 : 71-76.

Blundo G. 1991. "La brique, la terre et le puits : administration locale, 'factionalisme' et auto-promotion au Sénégal". In : Kwan Kaï Hong (ed), Jeux et enjeux de l'auto-promotion. Vers d'autres formes de coopération au développement. Paris : Presses universitaires de France/Genève : Institut universitaire d'études du développement : 103-133.

Blundo G.1992. "Le conflit dans l'Entente". Coopération et compétition dans les associations paysannes de Koungheul (Sénégal)". APAD Bulletin, 4 : 33-49

Blundo G. 1995. "Les courtiers du développement en milieu sénégalais". Cahiers d'Etudes Africaines, 35 (1) : 73-99.

Borhaug K. 1994. Local Government and Decentralization in Sub-Saharan Africa. An Annotated Bibliography. Working Paper. Bergen : Chr. Michelsen Institute.

Busacker D. a.o. 1990. L'Analyse Socio-Economique des Systèmes d'Exploitation Agricole et de la Gestion de Terroir dans le Bas-Saloum, Sénégal. Berlin : Technische Universität Berlin, Fachbereich Internationale Agrarentwicklung : 132.

Buijtenhuijs R. and C. Thiriot. 1995. Democratization in Sub-Saharan Africa 1992 - 1995. An overview of the literature. Leiden : African Studies Centre; Bordeaux : Centre d'Etude d'Afrique Noire.

Callaway B. and L. Creevey 1994. Islam, Women, Religion and Politics in West Africa. Boulder and London : Lynne Rienner Publishers.

Coulon C. and D.B. Cruise O'Brien 1989. "Senegal", In : D. Cruise O'Brien a.o., Contemporary West African States. Cambridge : Cambridge University Press : 145-164.

Diop S. 1993. "La transition démocratique : l'exemple du Sénégal", In : G. Conac (ed), L'Afrique en transition vers le pluralisme politique. Paris : Journées d'études sur "la démocratie pluraliste en Afrique", 12-13 december 1990.

Dramé H. 1966. Analyse et stratégies des courtiers de développement dans les organisations paysannes de le moyenne Casamance (Sénégal). Contribution to the seminar : Le développement négocié : courtiers, savoirs, technologies. Stuttgart, University of Hohenheim, 5 - 8 juin. 
Gellar S. 1996. Rural Councils and Decentralized Natural Resource Management in Senegal : the Challenge of Transforming Concepts into Reality. Manuscript.

Kante B. a.o. 1993. La Gestion des Ressources Naturelles par les Collectivités Locales. Séminaire organisé à l'Université de Saint Louis, du 3 au 5 Novembre 1992.

Kante B 1994. "Senegal's Empty Elections". Journal of Democracy, 5 (1) : 96-108.

Klein M.A. (ed) 1993. Breaking the chains : slavery, bandage, and emancipation in modern Africa and Asia. Madison, Wise. : University of Wisconson Press.

Lachenmann G. a.o. 1990. Organisations paysannes au Sénégal : comment renforcer les structures intermédiaires dans le processus de transformation socio-économique. Berlin : Institut Allemand de Développement.

Monimart M. 1989. Femmes du Sahel. La désertification au quotidien. Paris : Karthala et OCDE/Club du Sahel.

Olivier de Sardan J-P. 1995. Anthropologie et développement, Essai en socio-anthroplogie du changement social. Marseille : AP AD, Paris : Karthala.

Savané M.A. 1983. L'Impact de la Modernisation de l'Agriculture sur le Rôle et le Statut de la Femme au Sénégal. Genève : UNRISD.

Seck M. 1995. Rapport Annuel 1994. CER, Medina Sabakh. Snrech, S. 1988. The Dynamics of Organization in the Rural Sahel. Farmer's groups and rural organizations : limits and potential. Paris : OECD.

Sy M. 1996. "Arrondissement de Mérina Dakhar, Les racines de la Gouvernance locale, Gouvernance locale". Observatoire de la Décentralisation, : 5-6.

Venema L.B. 1978. The Wolof of Saloum : Social Structure and Rural Development in Senegal. Wageningen : PUDOC.

Venema L.B. a.o. 1996. Le savoir local et la gestion des ressources naturelles. Le cas de l'arrondissement Medina Sabalch, département Nioro du Rip. Rapport Scientifique.

Vengroff G. and A. Johnston 1989 Decentralization and the Implementation of Rural Development in Senegal, The View from Below. Lewiston, N.Y. : The Edwin Mellen Press.

\section{NOTES}

1.The real size of population is higher than the official one. Busacker a.o. (1990) estimates the total population as 46.712 inhabitants and the KAP-survey has an estimation of 4260 households (ménages), which means that the number of inhabitants is roughly around 40.000 .

2.The rural community of Medina Sabakh has a council with 29 members, of which 3 members are now deceased. The local village sections of the co-operative have 8 members in the council.

3.Africare is an American NGO. POGV stands for 'Projet d'Organisation et de Gestion Villageois' and is funded by IFAD. PNVA stands for 'Programme National de Vulgarisation Agricole', financed by the Senegalese government and the World Bank. ISRA is the Institut Sénégalais de Recherches Agricoles, financed by the state and foreign donors. Mission Norvégienne is a Norwegian NGO, financed by a Norwegian Protestant church and the Norwegian government. 
4.In 1996 PNVA and Peace Corps had Iwo field-agents, POGV and SODEVA each one. In 1995 SODEVA also had an extension worker in Kaymor but he returned to his natal village because he did not receive his salary. POGV is in contact with eleven villages, SODEVA with ten, PNVA with nine and Africaire with five. Peace Corps and ISRA are working in two villages. At last there is a Norwegian NGO, which has a project in one village only. Since 1996 PNVA is no longer active in the arrondissement.

5.This is also the case for the council of Medina Sabakh and, in fact, for the large majority of the rural councils in Senegal.

6. However, they can influence party politics by occupying positions in the party. So one of the teachers of Kaymor is secrétaire administratif de coordination at the level of the arrondissement.

7.The same accounts for the council of Medina Sabakh : only one woman and one "young man" were in the council. Here again the woman has died and has not replaced and the man in now 38 years old.

8. The community of Medina Sabakh counts 58 villages, 16 of them do have one or more councillors. The largest villages have more than one member (Medina Sabakh, Payoma, Ndiba Ndiayene, Diguirnar). Payoma, however is overrepresented. The regional distribution is as follows : Medina Sabakh : 4, Payoma : 5, Ndiba Diayene : 3, Fafila : 2, Djiquene : 2, Pakala : 2, Sanghab : 2, 9 villages $: 1$.

9.For example the council of Medina Sabakh has one artisan and Iwo slave-bom only, the other members (23) are all freeborn.

10.The council of Medina Sabakh has only one member not being Wolof (a Manding), although it counts three Peulh and six Toucouleur villages, among which a large village (Diguimar).

11.The remaining members are : representatives of the professional categories (agriculture, animal husbandry, handicraft) : 3 ; women's groups : 2 ; youth groups : 1 ; school committee : 1 ; representatives of geographical zones : 3 ; representatives of NGOs : ?

12.In 1993-95 the budget was respectively fCFA 5.200.000, 5.300.000 and 6.000.000. The chairman and the vice-chairman obtain a renumeration for their work and take 15 and $10 \%$ of the budget respectively, so that a quarter disappears as fixed costs.

13.In fact the committees are dependant of gifts from World Food Program (PAM) and from the Ministère des Eaux et Forêts, but these agencies did not help in a systematic way (Venema a.o. $1996: 7$ ).

14.In Sonkorong in 1995 both groupements ftminins were bankrupt. These groups had already run into financial difficulties earlier, resulting in a reshuffiing of the board, but without success. But also a religious group in Sonkorong had financial problems. In addition, the youth association of Kaymor was in fact bankrupt because of borrowing from the cash.

15.We are here referring to the Loi sur la Domaine Nationale of 1964. Except for the forét classée in the arrondissement ail the land is in the zone des terroirs. Here the state owns the land, but the usufruct of land was given back to the former owners. Under specific conditions land could be cleared, inherited and expropriated. This is decided by the rural council, with the local authorities acting as supervisors.

16. The village head also controls the access of cattle of strangers to the village weil and so indirectly decides who can make use of the pasture land, although in theory this should be decided by the council together with the sous-prefect (see section 2). 
17.In Medina Sabakh one councillor is mentioned to be very active. He is a farmer and also Imam of the village, although not the principal Imam. He is chairman of the local saving society, the Caisse Populaire, board member of the OIE of the ward Santhiabi and chairman of the Federation of OIEs in the arrondissement. His wife is president of the women's group of Santhiabi. Before the reform of the cooperatives he was the chairman of the co-operative of Medina Sabakh. He has had a thorough Koranic schooling.

18.In Medina Sabakh a teacher in French at the primary school was quite dynamic. He was the president of the OIE of Oawane and also the president of the board of visitors of the local saving bank, la Caisse Populaire. He was well-known because of his splendid orchard.

19.According to an estimation in 1988 about $10 \%$ of the rural population of Senegal would be involved in groups (Dramé 1996 : 6). This holds true for the arrondissement with a percentage of about 15-20\%, but if we include traditional groups such as daira. tontines too, the percentage would be far higher.

20.We studied the youth-association of Sonkorong and Kaymor, the women's groups of Thysse-Kymor, Kaymor, of Sonkorong (2) and of N'Dakhar, aGIE in Sonkorong and in Medina Sabakh (Gawane) and the two daira of Sonkorong.

\section{AUTEUR}

\section{BERNHARD VENEMA}

Vrije Universiteit Amsterdam - Dep. of Cultural Anthropology and Sociology of Development. Faculty of Social Science. De Boelelaan 1105, NL - 1081 HV Amsterdam (The Netherlands) 